\title{
Effects of Glucose on the Ultrastructure and Insulin Biosynthesis of Isolated Mouse Pancreatic Islets Maintained in Tissue Culture*
}

\author{
A. Andersson, J. Westman and C. Hellerström \\ Departments of Histology and Human Anatomy, The University of Uppsala, Uppsala, Sweden
}

Received: April 1, 1974, and in revised form: July 12, 1974

Summary. Tsolated mouse pancreatic islets were maintained in tissue culture for up to 12 days in glucose concentrations varying between 3.3 and $28 \mathrm{mM}$. A satisfactory ultrastructural preservation of the islet cells was found irrespective of the glucose concentration of the culture medium. While the B-cells of islets cultured in the lower glucose concentration showed slight degranulation, there was extensive degranulation and increased amounts of rough-surfaced endoplasmic reticulum after culture in the higher glucose concentration. The immunoreactive insulin content of islets cultured at $28 \mathrm{mM}$ glucose was markedly decreased and the insulin secretion during the culture period was much higher than that of islets cultured at $3.3 \mathrm{mM}$ glucose. The insulin biosynthesis, as reflected in the incorporation of ${ }^{3} \mathrm{H}$-leucine into gel chromato- graphed extracts of acid-ethanol soluble islet proteins, was studied either during the culture period or at the end of a 6-day culture in short-term incubations lasting for 90 or $180 \mathrm{~min}$. The results consistently showed that the biosynthesis of insulin proceeded at a high rate and remained regulated by glucose throughout the culture period. The continuous addition of newly synthesized and labelled insulin to the small intracellular insulin pool of the high-glucose cultured B-cells produced a very high specific radioactivity of the insulin.

Key words: Tissue culture, pancrea tic islets, degranulation, endoplasmic reticulum, insulin content, insulin release, insulin degradation, insulin biosynthesis.
Although the responses of the B-cell to an acute glucose challenge have been studied in great detail there is still little known about the long-term reactions of these cells to an increased extracellular glucose concentration. Thus, it is unclear whether the deficient insulin response to glueose and the diminished insulin reserves in diabetes mellitus are caused by a primary dysfunction of the cells or secondary functional exhaustion due to the hyperglycemic state. The experimental approach to this problem has been difficult mainly due to the lack of suitable techniques for long-term studies of isolated B-cells in a system separate from all the complex influences which occur in vivo. In the present study a recently developed technique for in vitro culture of intact isolated islets [1] has been utilized in an attempt to overcome these difficulties. The insulin content and the biosynthesis of insulin have been analysed in mouse pancreatic islets maintained in culture at widely different glucose concentrations. In addition, the insulin release to the culture medium and the glucose-dependent variations of the ultrastructure of the cultured B-cells have been evaluated.

\section{Materials and Methods}

\section{A. Tissue Culture Technique}

Male NMRI mice (Anticimex AB, Stockholm, Sweden) weighing $30-35 \mathrm{~g}$ were starved over-night before the experiments. Isolated islets were obtained by digestion of the pancreas with collagenase (Worthington Biochemical

* Presented in part at the Congress of the European Association for the Study of Diabetes, Madrid 1972.
Company, Freehold, New Jersey, U.S.A.) mainly as described by Howell and Taylor [2] and under aseptic conditions. Groups of isolated islets were then cultured as recently published [1] in plastic culture dishes $(\mathrm{A} / \mathrm{S}$ NUNC, Roskilde, Denmark) containing $5 \mathrm{ml}$ of tissue culture medium TC 199 supplemented with $10-20 \%$ calf serum (Statens Bakteriologiska Laboratorium, Stockholm, sweden), penicillin (100 U/ml) and streptomycin $(0.1 \mathrm{mg} / \mathrm{ml})$. About $30-60$ islets were cultured in each dish. If not stated otherwise the final glucose concentration in the medium was adjusted to $3.3 \mathrm{mM}$ (low-glucose medium) or $28 \mathrm{mM}$ (high-glucose medium). The medium was changed on the fourth day of culture and then every second day up to a culture period of either 6 or 12 days. The cultured islets were harvested by trypsinization for $15 \mathrm{~min}$ in a Cat+- and $\mathrm{Mg}^{++}$-free $0.25 \%$ (w/v) trypsin solution $(1: 300)$ followed by two washings in Hanks solution. Direct comparisons with islets harvested by free-hand dissection instead of trypsinization showed almost identical glucose responses both with regard to glucose oxidation [3] and insulin release, indicating that trypsin lacked injurious effects on cultured islets.

\section{B. Ultrastructural Studies}

Groups of islets were fixed by immersion either immediately after the isolation procedure or after 6 or 12 days culture. The fixation was performed for one hour in a mixture of $1 \%(\mathrm{v} / \mathrm{v})$ formaldehyde and $2 \%(\mathrm{v} / \mathrm{v})$ glutaral dehyde, adjusted to pH 7.4 in a $0.05 \mathrm{M}$ sodium cacodylate buffer. The specimens were postfixed in $1 \%(\mathrm{w} / \mathrm{v})$ osmium tetroxide in $0.06 \mathrm{M}$ phosphate buffer adjusted to $\mathrm{pH} 7.4$ After dehydration the islets were embedded in Epon ${ }^{\circledR}$. Thin sections were prepared on an LKB ultrotome (LKBProdukter, Stockholm, Sweden), picked up on one hole grids and stained with uranyl acetate followed by lead citrate. The electron microscopy was carried out with a JEOL TEM $100 \mathrm{~B}$ microscope. Altogether 31 islets were studied, 17 of which had been cultured for 6 days and 10 for 12 days in either $3.3 \mathrm{mM}$ or $28 \mathrm{mM}$ glucose. Four noncultured islets were examined for comparative purposes. 


\section{Insulin Content of the Cultured Islets}

Islets were eultured for $1-12$ days in either $3.3 \mathrm{mM}$ glueose or $28 \mathrm{mM}$ glucose. Groups of $20-30$ islets were then homogenized in $50 \mu \mathrm{l}$ distilled water in a Perspex microhomogenizer. The protein content of the homogenate was determined in duplicates ( $10 \mu \mathrm{l}$ each) [4] with bovine plasma albumin (BPA; Fraction V; Armour Pharmaceutical Co., Ltd., Eastbourne, England) as a standard. The remaining homogenate was extracted with $400 \mu l$ acid ethanol ( $15 \mathrm{ml} 12 \mathrm{~N}$ HCl per litre $70 \%$ ethanol) for 24 hrs at $+4^{\circ} \mathrm{C}$ and stored at $-20^{\circ} \mathrm{C}$ prior to the radioimmunoassay of insulin [5]. This was performed on duplicate samples using crystalline mouse insulin as a standard. The error of a single determination was $\pm 12 \%$.

\section{Insulin Accumulation and Degradation in the Culture} Medium

For these studies islets were cultured for $1-7$ days in either $3.3 \mathrm{mM}$ glucose or $16.7 \mathrm{mM}$ glucose. Portions of the culture medium, $100 \mu \mathrm{l}$ each, were removed daily and stored at $-20^{\circ} \mathrm{C}$ prior to insulin assay. In order to determine the approximate rate of insulin degradation in the medium during the culture period, tracer amounts of ${ }^{125}$ I-insulin were added to the culture dishes [6]. An estimate of the insulin degradation was then obtained from the percentage of the radioactivity in $100 \mu \mathrm{l}$ culture medium which was precipitated by $5 \%(\mathrm{w} / \mathrm{v})$ TCA at various times after the beginning of the culture or after change of the culture medium.

\section{E. Biosynthesis of Insulin in the Cultured Islets}

The biosynthesis of insulin was studied by incubation of the cultured islets with ${ }^{3} \mathbf{H}$-labelled leucine. These experiments were performed either as short-term incubations after the culture period or by addition of the labelled amino acid to the medium during the culture period. The two sets of experiments will be described separately below.

E. 1. Insulin Biosynthesis in Short-Term Incubations. After a culture period of 6 days in either $3.3 \mathrm{mM}$ glucose or $28 \mathrm{mM}$ glucose islets were trypsinized as described above and placed in small incubation vials [7] in groups of 25 islets each. Other groups of freshly isolated islets were incubated in a similar way. The medium consisted of $250 \mu \mathrm{l}$ bicarbonate buffer [8] supplemented with $0.2 \mathrm{mg} / \mathrm{ml}$ $\mathrm{BPA}, 100 \mu \mathrm{Ci} / \mathrm{ml}$ of $\mathrm{L}$-leucine-4,5- ${ }^{3} \mathrm{H}$ (Spec. act. $38 \mathrm{Ci}$ ) mmole; The Radiochemical Centre, Amersham, England) and $20 \mathrm{\mu g} / \mathrm{ml}$ each of twelve naturally occurring amino acids (arginine, cysteine, glutamine, histidine, isoleucine, lysine, methionine, phenylalanine, threonine, tryptophan, tyrosine, valine) according to Eagle [9] except that leucine was omitted. Glucose was added to the medium to give a final concentration of either $3.3 \mathrm{mM}$ or $16.7 \mathrm{mM}$. Incubations were performed under continuous shaking in a water bath at $+37^{\circ} \mathrm{C}$ for either 90 or $180 \mathrm{~min}$ in a gas phase of $95 \% \mathrm{O}_{2}+5 \% \mathrm{CO}_{2}$. The incubated islets were then washed twice in non-radioactive buffer containing cold leucine $(10 \mathrm{mM})$ and homogenized in $50 \mathrm{ul}$ distilled water. Samples $(2 \times 10 \mu \mathrm{l})$ of the homogenate were taken for protein determinations [4]; the residual homogenate being extracted in $400 \mu \mathrm{l}$ acid ethanol for $20 \mathrm{hrs}$ at $+4^{\circ} \mathrm{C}$. After centrifugation and addition of $1 \mathrm{mg}$ crystalline ox insulin as carrier protein the acid ethanol soluble proteins were precipitated with ether-ethanol [10], stored at $-20^{\circ} \mathrm{C}$ and further processed as described below.

Carrier insulin was omitted in some experiments, in which the immunoreactivity of the extracted insulin was measured (see below). Separate experiments indicated a recovery after the ether-ethanol precipitation of $78 \pm 1 \%$ $(n=4)$ of added ${ }^{125} \mathrm{I}$-insulin by this extraction procedure.

E. 2. Insulin Biosynthesis during the Culture Period. Tritium labelled leucine was added directly to the tissue culture medium in a concentration of $50 \mu \mathrm{Ci} / \mathrm{ml}$. The glucose concentration of the medium was adjusted to $6.7 \mathrm{mM}$. Non-radioactive leucine was thus absent from the culture medium except for the amounts contained in the calf serum. The specific activity of the labelled amino acid was calculated as approximately $2 \mathrm{Ci} / \mathrm{mmole}$. Insulin synthesized in the cultured islets was labelled by exposing the islets to ${ }^{3} \mathrm{H}$-leucine for either $3 \mathrm{hrs}$ or 3 days. The radioactivity incorporated was then measured either immediately or after three days, during which time the islets were cultured further in a non-radioactive medium (chase period). During the non-radioactive period the culture medium consisted of a non-radioactive standard medium (TC $199+20 \%$ calf serum) containing approximately 0.75 mmoles L-leucine. Before measuring the radioactivity the cultured islets were harvested from the bottom of the culture dish and extracted as described above.

\section{F. Gel Chromatography}

The precipitated islet extracts were redissolved in 300 ul $3 \mathrm{M}$ acetic acid containing $1 \mathrm{mg}$ BPA. Gel chromatography of the samples was subsequently performed in $3 \mathrm{M}$ acetic acid at room temperature on a column $(1 \times 67 \mathrm{~cm})$ of Sephadex G-50 (Pharmacia Fine Chemicals AB, Uppsala, Sweden) with a flow rate of $15 \mathrm{ml}$ per hour. The column was calibrated with Dextran Blue 2000, BPA, cy tochrome $\mathrm{C}$, bovine insulin and bovine-porcine glucagon. The optical density of the eluate at $280 \mathrm{~nm}$ was recorded continuously by an absorptiometer (Uvicord II, LKBProdukter AB, Stockholm, Sweden). A $0.5 \mathrm{ml}$ sample of each fraction $\left(1 \mathrm{ml}\right.$ ) was mixed with $10 \mathrm{ml}$ Instagel ${ }^{\circledR}$ and counted in a liquid scintillation. spectrometer (Packard Tricarb Model 3380; Ill., U.S.A.). To characterize further the material in the radioactive pealss polyacrylamide gel electrophoresis was carried out [11] and the radioactivity and the immunoreactive insulin content of the sliced gels was determined [12].

Islet homogenates to which carrier insulin had not been added were used for estimation of the specific radioactivity of the extracted insulin. These samples were chromatographed on a Sephadex ${ }^{\circledR}$ G-50 column similar to that described above. Each fraction was divided into two aliquots one of which was used for determination of the radioactivity, while the other one was freezedried. The dried residue was dissolved in $0.5 \mathrm{ml} 0.04 \mathrm{M}$ phosphate buffer containing $2 \mathrm{mg} / \mathrm{ml} \mathrm{BPA}$, and the immunoreactive insulin content measured [5]. The approximate specific radioactivity of the extracted insulin was calculated by dividing the mean value for the radioactivity (cpm) incorporated into each of the four fractions comprising the maximum of the insulin peak with the mean value for their respective immunoreactive insulin content (cf. Sando et $a l .,[13])$.

A quantitative evaluation of the effects of glucose on the incorporation of ${ }^{3} \mathbf{H}$-leucine into the proinstulin and insulin peaks after incubation periods of various lengths was performed according to Asplund [14] and the results expressed as counts per min/ $\mu \mathrm{g}$ protein in the islet homogenates. The total number of cpm in each peak was determined by assuming it was a Gaussian distribution curve, and adding the numbers of cpm within each of the proinsulin and insulin regions of the chromatograms.

\section{G. Immunoadsorption}

Fractions containing either proinsulin or insulin separated by gel chromatography of extracts from cultured or non-cultured islets were pooled and redissolved in $0.04 \mathrm{M}$ phosphate buffer, $\mathrm{pH} 7.4$, supplemented with $2 \mathrm{mg} / \mathrm{ml}$ BPA. Each pooled sample was then subjected to immunoadsorption in the modification of Berne [15] by incubation for $2 \mathrm{hrs}$ with excess antibovine insulin antiserum coupled to activated Sepharose 4 B beads (Phar- 
macia Fine Chemicals, Uppsala, Sweden). After incubation the beads were washed twice in the same buffer, solubilized in Soluene ${ }^{\oplus}$ and counted in $10 \mathrm{ml}$ of a scintillation cocktail. Control values obtained by incubation of samples of the two pools with normal guinea-pig serum proteins coupled to Sepharose beads were subtracted from the experimental values.

\section{Results}

\section{Ultrastructural Studies}

a) Islets Cultured at $3.3 \mathrm{mM}$ Glucose. The cultured islet cells generally showed a satisfactory ultrastructural preservation with few, if any, necrotic or degenerating cells. As can be seen in Fig. 1 the cells were arranged in an epithelioid manner without conspicuous intercellular spaces or cisternae. Numerous secretory granules in each cell made it possible to classify the cells into $A_{2^{-}}$and $B$-cells, while $A_{1}$-cells could not be recognized with certainty. As compared to normal, non-cultured mouse islet cells the content of secretory granules was somewhat decreased in the cultured Bcells, whereas the granule content of the $A_{2}$-cells appeared normal. The nuclei were located centrally and were rounded with occasional indentations, especially in the $\mathrm{A}_{2}$-cells. The rough endoplasmic reticulum was poorly developed, while mitochondria tended to be more numerous than in non-cultured islets. Lysosomelike bodies were found occasionally, sometimes containing structures resembling secretory granules. Fibroblasts were seldom seen and occurred with about the same frequency as in non-cultured islets. There were no marked differences in ultrastructural appearance between islets cultured for 6 and 12 days.

b) Islets Cultured at $28 \mathrm{mM}$ Glucose. These islet cells, like those described above, exhibited a very good ultrastructural preservation. However, they differed from those cultured in a low-glucose medium in two major respects. Most conspicuous was the marked degranulation of the B-cells, each cell retaining only a few granules, often located close to the cellular membrane. Nevertheless, the few secretory granules still present were sufficient to allow identification of the type of cell. Again, the $\mathrm{A}_{\mathbf{2}}$-cells had a normal granule content. Agranular or fibroblastoid cells were not recognized.

The other distinctive feature was the abundance of rough endoplasmic reticulum, which filled a large part of many cell profiles. In addition, numerous free ribosomes were present in the cytoplasm, which also contained smooth-surfaced vesicles of varying sizes. The mitochondria were of normal appearance. Occasional lipid bodies and lysosomes were recognized and cilia-like structures occurred in a few $B$-cells. There was no morphological evidence of glycogen accumulation. On the whole, islets cultured for 6 and 12 days had the same electron-microscopic appearance except that degranulation seemed to be less marked in cells maintained in culture for the longer time period.

\section{Insulin Content of the Cultured Islets}

The insulin contents of both cultured and noncultured islets are given in Fig. 3. Culture in the lower glucose concentration caused the islet insulin content to diminish to about $55 \%$ of that in the non-cultured controls by the sixth day of culture and to about $30 \%$ by the twelfth day. When islets were cultured at the higher glucose concentration there was a much more rapid and pronounced depletion of the islet insulin content. Already by the third day of culture the insulin content of these islets had decreased to about $4 \%$ of the control value. The insulin content subsequently remained essentially constant throughout the culture period.

\section{Insulin Accumulation and Degradation in the Culture Medium}

An attempt to estimate the degradation of insulin in the culture medium was made by measurements of the ${ }^{125}$ I-activity precipitated by TCA in the medium at various intervals after addition of the labelled hormone. Irrespective of the glucose concentration of the culture medium there was a rapid fall in the precipitated activity during the first day of incubation and also immediately after changing the culture medium (Fig. 4). Subsequently the degradation proceeded considerably more slowly and the further loss of precipitable radioactivity did not exceed $15 \%$ of the initial value over a period of 3 days. These results seem to indicate that except for the period immediately after the beginning of the culture or change of the culture medium insulin degradation was not a major source of error in the measurements of insulin accumulation in the culture medium. No corrections for insulin loss during culture have therefore been made. Neither has any correction been made for the small amounts of insulin initially present in the serum fraction of the culture medium. This was found to represent less than $1 \%$ of the insulin released from the islets.

The accumulation of insulin in the culture medium is illustrated in Fig. 5. It is clear that there was a much faster and more pronounced accumulation during culture in a high glucose concentration (16.7 $\mathrm{mM}$ ) than at $3.3 \mathrm{mM}$. The largest liberation of insulin occurred during the first day of culture, when the majority of islets was still freely suspended in the medium. At the high glucose concentration there was subsequently a fairly constant increase of the insulin concentration. By contrast, insulin accumulation in the low-glucose medium was small or even absent except on the first day of culture and after changing the medium. Even then it was less than $15 \%$ of that in the high-glucose medium.

\section{Insulin Biosynthesis in Short-Term Incubations}

An example of the Sephadex G-50 profile of partially purified proteins from islets cultured first for 6 days in a non-radioactive medium and subsequently incubated 


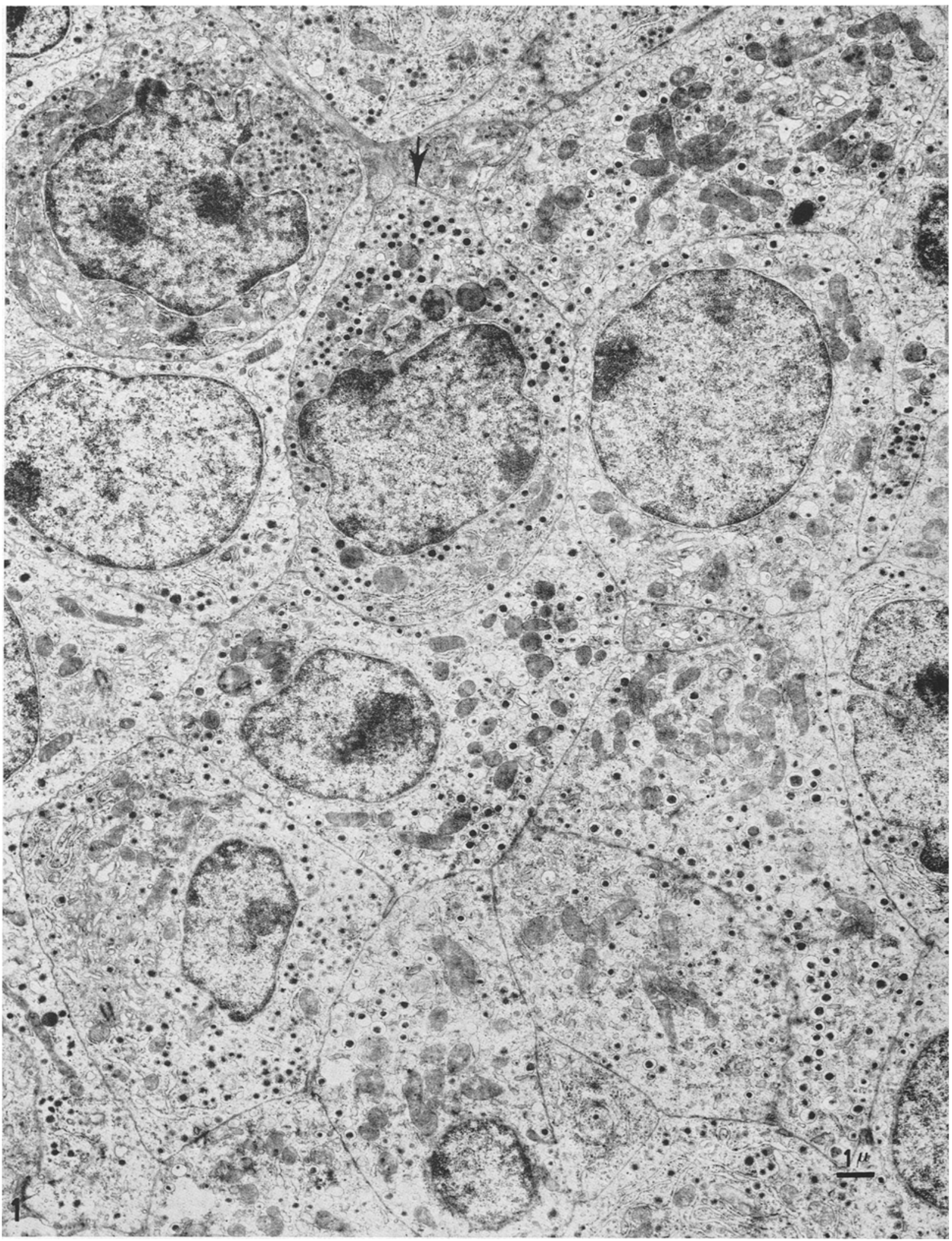

Fig. 1. Islet cells cultured for 6 days in the low-glucose medium (3.3 mM). The majority of the cells are B-cells containing secretory granules surrounded by wide sacs. The endoplasmic reticulum is poorly developed in these cells. A well granulated $\mathrm{A}_{2^{n}}$ cell is indicated by the arrow. $\times 6000$ 


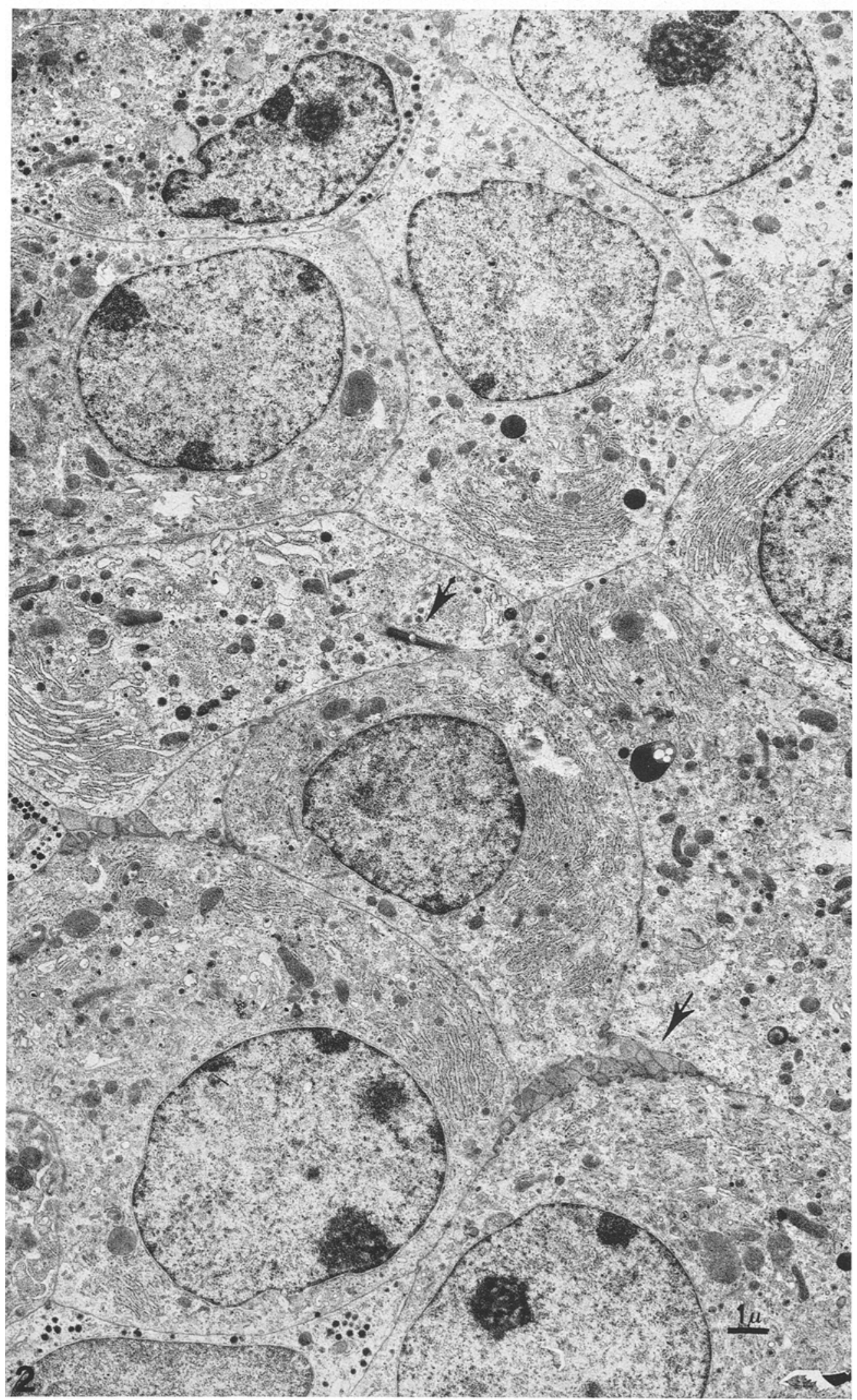

Fig. 2. Islet cells cultured for 12 days in the high-glucose medium (28 mM). An $A_{2}$-cell is seen in the upper left corner. Note the paucity of secretory granules in the other cells, most of which can be identified as $B$-cells. These cells have an abundant rough endoplasmic reticulum. The upper arrow points to a cilium and the lower arrow to a small intercellular cisternae with protrusions from adjacent cells. $\times 6000$ 


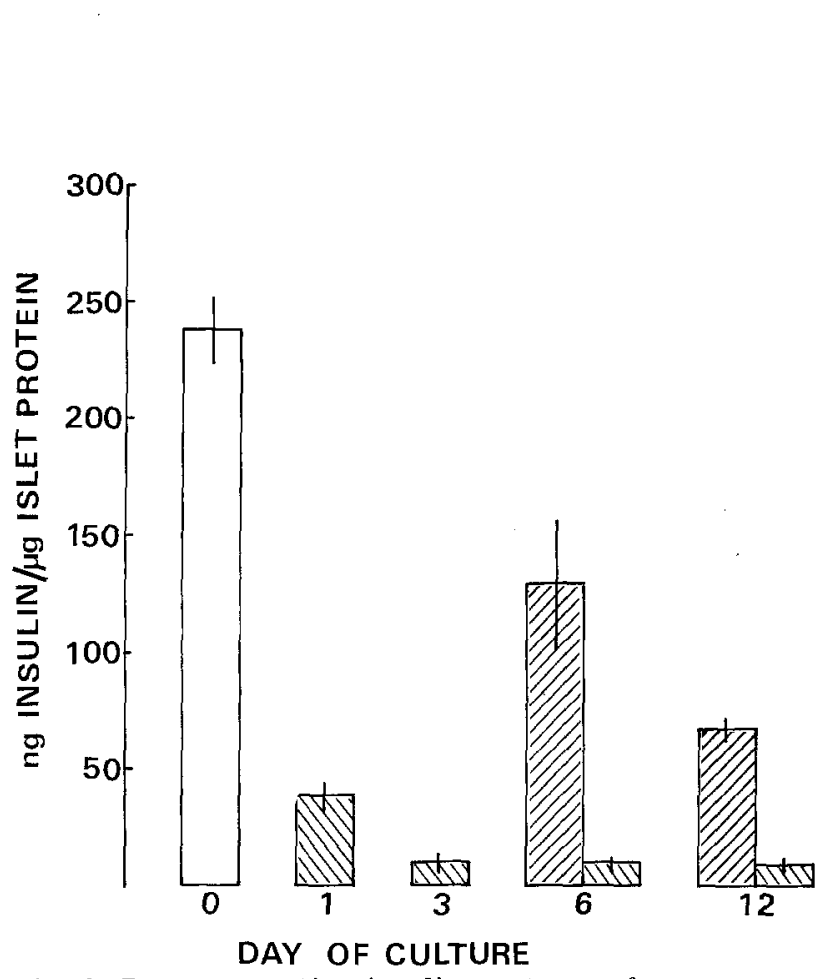

Fig. 3. Immunoreactive insulin contents of mouse pancreatic islets maintained in tissue culture for various periods of time. ( $\square$ ) non-cultured islets; ( $\mathbb{W}$ ) cultured in $28 \mathrm{mM}$ glucose; (")":) cultured in $3.3 \mathrm{mM}$ glucose. Each bar represents the mean $\pm S$. E.M. of $7-18$ determinations

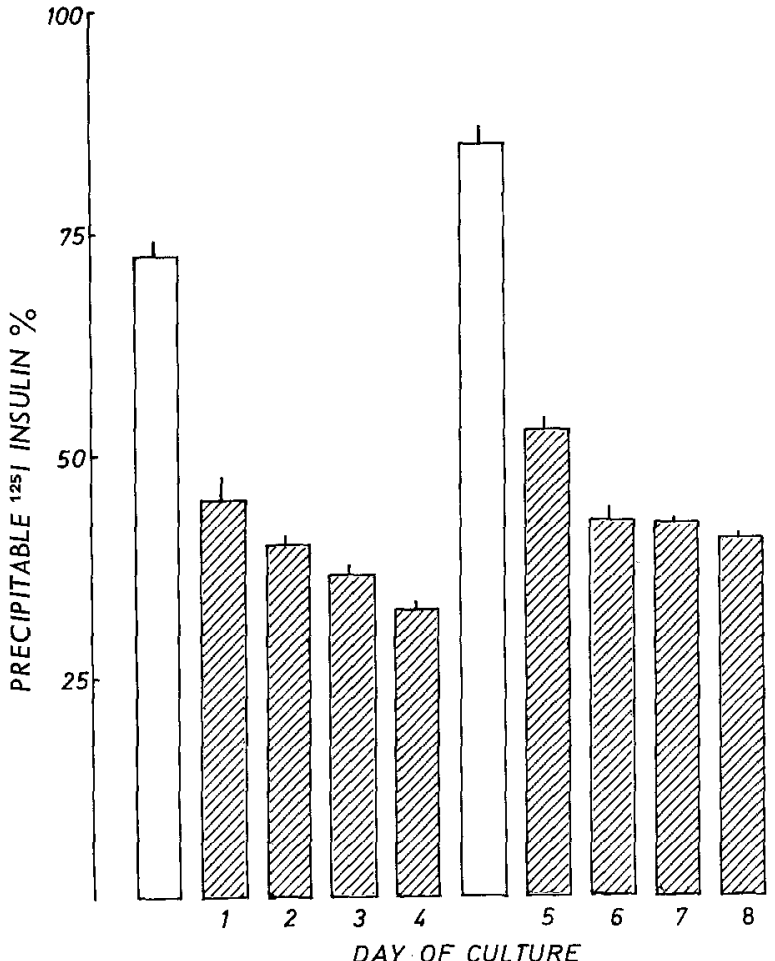

Fig. 4. Degradation of ${ }^{125}$ I-insulin added to the culture dishes on the first or fifth day of culture. Each culture dish contained $5 \mathrm{ml}$ TC 199 (16.7 mM glucose, $10 \%$ calf serum) and $30-60$ islets. Values represent radioactivity precipitated with $5 \%$ TCA expressed as percentage of total radioactivity. Open bars indicate the values at the beginning of the culture or after the change of the culture medium. Each bar represents the mean 土S. E.M. of $8-10$ determinations

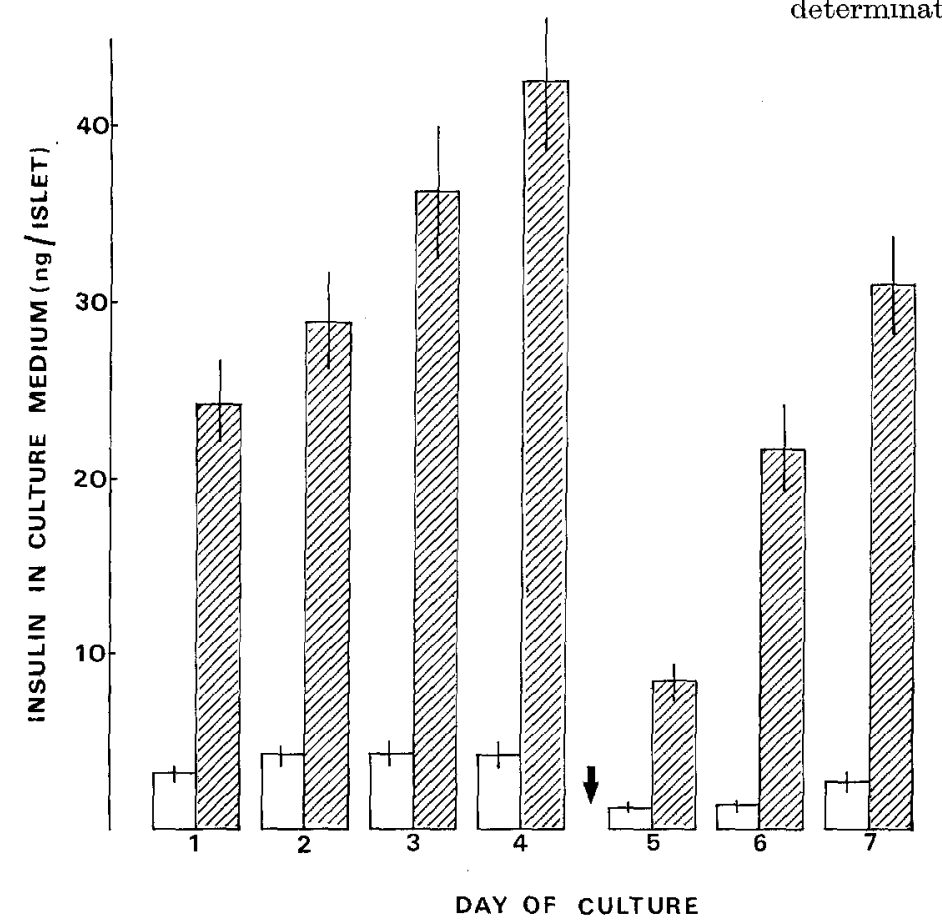

Fig. 5. Accumulation of immunoreactive insulin in the TC 199 medium during culture in $3.3 \mathrm{mM}(\square)$ or $16.7 \mathrm{mM}$ (yin) glucose. The medium was changed after four days culture (arrow). Each bar represents the mean \pm S. E.M. of $13-28$ observations 
for $180 \mathrm{~min}$ in the presence of ${ }^{3} \mathrm{H}$-leucine is given in Fig. 6. There were three distinct radioactive peaks and of these the first $(\mathbf{I})$ eluted together with albumin in the void volume and the third (III) with the carrier insulin. Islet extracts run on the column without carrier insulin showed a major peak of immunoreactive insulin corresponding to peak III. In addition, a considerably smaller immunoreactive insulin peak was observed in the region of peak II. The position of peak II corresponded to that which might be expected from a protein with a molecular weight of about 9000 . Polyacrylamide gel electrophoresis of this material at $\mathrm{pH} 8.9$ showed that it migrated more slowly than each of the two mouse insulins. In addition, limited tryptic hydrolysis $(0.05 \mu \mathrm{g}$ trypsin for $15 \mathrm{~min}$ at $\mathrm{pH} 7.4)$ of the pooled and freeze-dried material of peak II caused this to migrate with insulin (peak III) upon rechromatography on Sephadex G-50. On the basis of these observations it was concluded that peak II contained mouse proinsulin and peak III mouse insulin. In order to get an idea of the extent to which peaks II and III were contaminated with proteins other than proinsulin and insulin, fractions from each peak were pooled and tested by immunoadsorption. It was found that about $69 \%$ of the TCA precipitable radioactivity of peak II and about $71 \%$ of that of peak III were bound by the

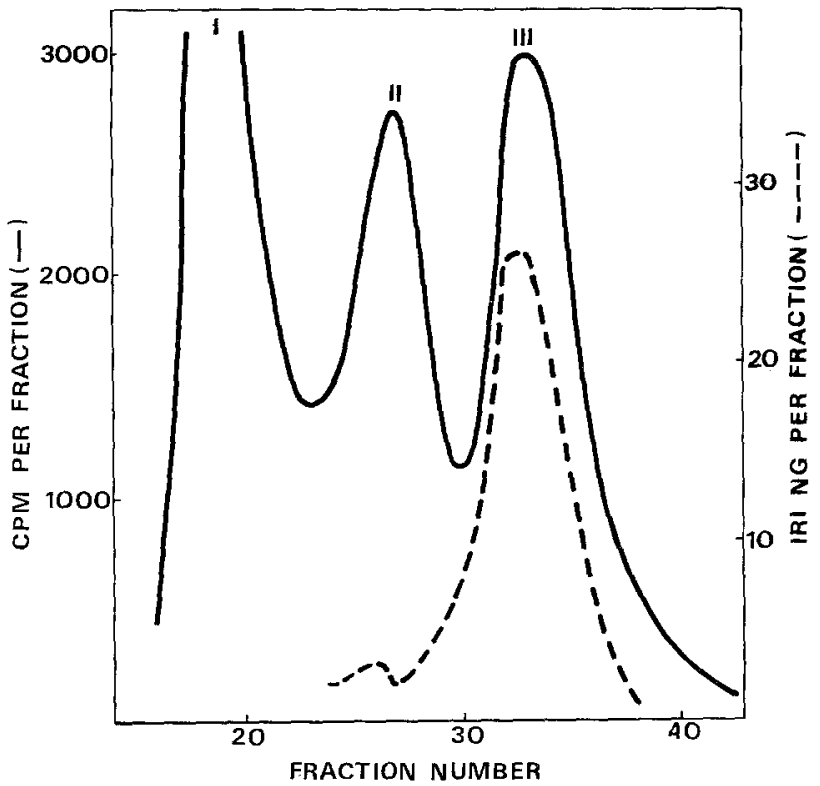

Fig. 6. Gel chromatographic profile of ${ }^{3} \mathrm{H}$-leucine incorporation into acid-ethanol soluble proteins from isolated pancreatic islets cultured for 6 days in $28 \mathrm{mM}$ glucose and subsequently incubated for $180 \mathrm{~min}$ in a bicarbonate buffered medium containing $16.7 \mathrm{mM}$ glucose and $100 \mu \mathrm{Ci} / \mathrm{ml}{ }^{3} \mathrm{H}$-leucine (continuous line). The elution pattern of insulin immunoreactivity in a similar extract is also shown (interrupted line)

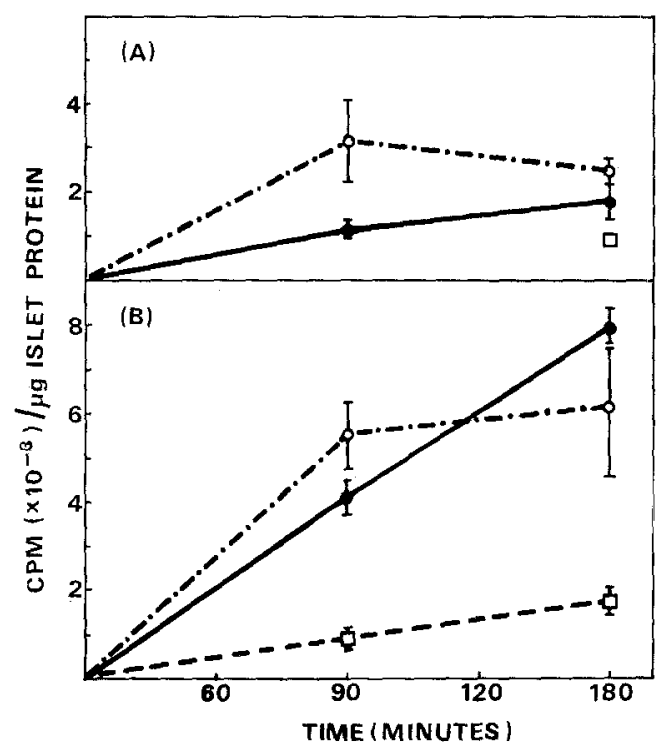

Fig. 7. Time-course of ${ }^{3} \mathrm{H}$-leucine incorporation into both proinsulin and insulin (sum of cpm in peaks II and III in the gel-chromatograms) of non-cultured islets (-0) or of islets cultured for 6 days in either $3.3 \mathrm{mM}$ glucose $(\square-\cdots \square)$ or $28 \mathrm{mM}$ glucose $(0 \cdot \ldots \cdot-\cdot 0)$. The incorporation experiments were carried out at $3.3 \mathrm{mM}$ glucose $(\mathrm{A})$ or $16.7 \mathrm{mM}$ glucose (B). Each point represents the mean \pm S.E.M. of $5-7$ experiments

Table 1. Effects of glucose concentration and duration of the incubation period on the incorporation of ${ }^{3} H$-leucine into proinsulin (PI) and insulin (I) of non-cultured isolated pancreatic islets $(0)$, islets cultured for six days in the low-glucose medium $(6 d-3.3 \mathrm{mM})$ or in the high-glucose medium $(6 d-28 \mathrm{mM})$. Each figure represents the mean \pm S.E.M. of $5-7$

\begin{tabular}{|c|c|c|c|c|c|}
\hline \multirow[t]{3}{*}{ Islets } & \multirow[t]{3}{*}{ Fraction } & \multicolumn{4}{|c|}{${ }^{3} \mathrm{H}$-leucine incorporation $\left(\mathrm{cpm} \times 10^{-1} / \mu \mathrm{g} \text { islet protein }\right)^{\mathrm{a}}$} \\
\hline & & \multicolumn{2}{|c|}{$3.3 \mathrm{mM}$ glucose } & \multicolumn{2}{|c|}{$16.7 \mathrm{mM}$ glucose } \\
\hline & & $90 \mathrm{~min}$ & $180 \min$ & $90 \mathrm{~min}$ & $180 \min$ \\
\hline \multirow[t]{3}{*}{0} & PI & $97 \pm 16$ & $101 \pm 22$ & $333 \pm 33$ & $415 \pm 16$ \\
\hline & I & $18 \pm 6$ & $76 \pm 19$ & $77 \pm 11$ & $384 \pm 26$ \\
\hline & $P I+I$ & $115 \pm 22$ & $177 \pm 40$ & $410 \pm 42$ & $799 \pm 40$ \\
\hline \multirow[t]{3}{*}{$6 \mathrm{~d}-3.3 \mathrm{mM}$} & PI & - & $56 \pm 18$ & $65 \pm 8$ & $88 \pm$ \\
\hline & I & - & $32 \pm 11$ & $24 \pm 5$ & $86 \pm 12$ \\
\hline & $\mathrm{PI}+\mathrm{I}$ & - & $88 \pm 28$ & $89 \pm 11$ & $174 \pm 18$ \\
\hline \multirow[t]{3}{*}{$6 \mathrm{~d}-28 \mathrm{mM}$} & PI & $156 \pm 46$ & $92 \pm 8$ & $278 \pm 33$ & $249 \pm 46$ \\
\hline & & $159 \pm 53$ & $157 \pm 19$ & $270 \pm 50$ & $362 \pm 110$ \\
\hline & $\mathrm{PI}+\mathrm{I}$ & $315 \pm 95$ & $249 \pm 25$ & $548 \pm 75$ & $612 \pm 156$ \\
\hline
\end{tabular}

\footnotetext{
a Approximately $0.5 \mu \mathrm{g}$ protein/islet.
} 
insulin antibodies, there being no differences between cultured and non-cultured islets. These results suggest that peak II was predominantly proinsulin and that, in addition to insulin, peak III contained the liberated C-peptide, which is not bound by insulin antibodies.

A quantitative evaluation of the incorporation of ${ }^{3} \mathrm{H}$-leucine into proinsulin and insulin of freshly isolated and cultured islets is given in Fig. 7 and Table 1. As can be seen in the Figure the non-cultured islets displayed linear incorporation rates for up to $3 \mathrm{hrs}$ when incubated in media containing either low or high glucose concentrations. Islets cultured in the lowglucose medium also exhibited a linear incorporation rate when incubated in a high glucose concentration. The incorporation was, however, only about $20 \%$ of that observed for the non-cultured islets. A considerably higher initial rate of insulin synthesis was recorded for islets cultured in the high-glucose medium and subsequently incubated with $16.7 \mathrm{mM}$ glucose for $3 \mathrm{hrs}$. In this case, however, the rate of incorporation tended to decrease after $90 \mathrm{~min}$ incubation. Islets incubated at a glucose concentration of $3.3 \mathrm{mM}$ had a very low rate of incorporation if they had been previously cultured in the low-glucose medium. Again, islets cultured in the high-glucose medium exhibited the fasted incorporation rate during the initial $90 \mathrm{~min}$ of incubation. After this there was, however, no further increase of the radioactivity.

Table 1 shows a quantitative evaluation of elution profiles from extracts of non-cultured and cultured islets incubated in a medium containing either $3.3 \mathrm{mM}$ or $16.7 \mathrm{mM}$ glucose. In all cases glucose appeared to stimulate the biosynthesis of insulin, particularly in the non-cultured islets. In the latter, glucose produced about a four-fold increase in the incorporation, whereas the cultured islets only doubled their content of radioactive insulin irrespective of the glucose concentration in the medium during the culture period. As compared to the non-cultured islets, however, the high-glucose cultured islets displayed an enhanced rate of incorporation, even when incubated at $3.3 \mathrm{mM}$ glucose. Furthermore, after $90 \mathrm{~min}$ incubation the non-cultured islets had a statistically higher $(p<0.001)$ radioactivity in the proinsulin peak than in the insulin peak at either glucose concentration. This difference disappeared, however, after incubation for $180 \mathrm{~min}$. In the cultured islets there was a higher proinsulin peak, seen only after culture in the low-glucose medium and a subsequent incubation for $90 \mathrm{~min}$ at $16.7 \mathrm{mM}$ glucose.

The extent of conversion of proinsulin to insulin was calculated from the figures in Table 1 by dividing the radioactivity in the insulin peak (peak III) by the total amount of radioactivity incorporated into peaks II and III. In the non-cultured islets between 14-20\% of the radioactivity was recovered in the insulin peak after $90 \mathrm{~min}$, independent of the glucose concentration of the incubation medium. The corresponding figure after the longer incubation period was $43-48 \%$. Islets cultured in the low-glucose medium had $27 \%$ of the radioactivity in insulin after $90 \mathrm{~min}$ incubation in $16.7 \mathrm{mM}$ glucose. After $180 \mathrm{~min}$ these islets had $36 \%$ of the activity in the insulin peak when incubated in $3.3 \mathrm{mM}$ glucose and $49 \%$ in $16.7 \mathrm{mM}$ glucose. These figures differ considerably from those obtained with islets that had been cultured in the high-glucose medium. The latter specimens already showed $50 \%$ conversion after 90 min incubation in both $3.3 \mathrm{mM}$ and $16.7 \mathrm{mM}$ glucose. The corresponding figures for $180 \mathrm{~min}$ incubation were $63 \%$ and $59 \%$.

\section{Insulin Biosynthesis during Culture}

Gel chromatography profiles of extracts from islets cultured in the presence of ${ }^{3} \mathrm{H}$-leucine are shown in Fig. 8. The cultured islets accumulated a considerable amount of labelled insulin and proinsulin during a labelling period of three days. As expected, there was a

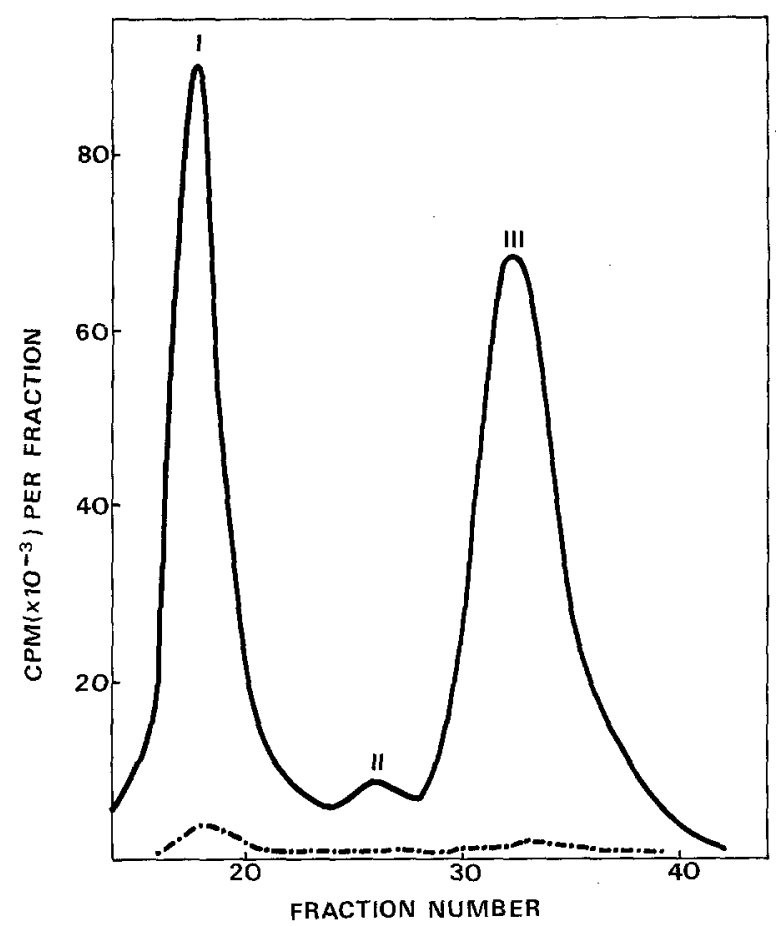

Fig. 8. Gel chromatographic profiles of ${ }^{3} \mathrm{H}$-leucine incorporation into acid-ethanol soluble proteins from isolated mouse islets maintained in tissue culture. One group of islets was cultured for 3 days in a medium containing 6.7 $\mathrm{mM}$ glucose and $50 \mu \mathrm{Ci} / \mathrm{ml}{ }^{3} \mathrm{H}$-leucine (continuous line), and the second group was first cultured for 3 days in this medium and subsequently for 3 additional days in a nonradioactive medium containing the same glucose concentration (interrupted line)

much higher activity in the insulin than in the proinsulin peak; the former comprising over $90 \%$ of the total radioactivity in these two peaks. When the labelling period was followed by an equally long period in non-radioactive medium almost all the radioactive proteins disappeared indicating, as expected, a turnover of the islet proteins throughout the whole culture period. When labelling was confined to only three 
hours on the third day after islet explantation the elution profile was very similar to that described above for islets labelled in short-term incubation.

\section{Specific Activity of the Insulin}

The specific activity of the insulin of the noncultured islets was found to be $50 \pm 10 \mathrm{cpm} / \mathrm{pmole}$ immunoreactive insulin $(n=3)$ after incubation for $180 \mathrm{~min}$ at $16.7 \mathrm{mM}$ glucose in the presence of ${ }^{3} \mathrm{H}$ leucine. The corresponding value for islets previously cultured for six days in the high-glucose medium was $450 \pm 50 \mathrm{cpm} / \mathrm{pmole}$ insulin $(\mathrm{n}=3)$. If the incorporation of ${ }^{3} \mathrm{H}$-leucine was allowed to proceed during the first three days of culture with $16.7 \mathrm{mM}$ glucose in the culture medium the specific activity of the insulin recovered after gel filtration had increased to not less than $5300 \pm 750 \mathrm{cpm} /$ pmole insulin $(\mathrm{n}=3)$.

\section{Discussion}

It has previously been reported that isolated islets kept in tissue culture show secretory responses consistent with those observed in noncultured islets and a morphology corresponding to that observed in vivo $[1,16,17,18,19]$. In addition, maintenance of a mixed endocrine-exocrine pancreatic cell population or of islet tumour cells either in organ culture [20,21, 22] or in monolayer culture $[23,24,25,26,27]$ appears compatible with a well preserved insulin biosynthesis. The electron microscopic appearance of the islets cultured in the present study strongly suggests that the islet cells remained viable throughout the entire culture period. In addition, characteristic ultrastructural changes occurred in islets cultured at the higher glucose concentration $(28 \mathrm{mM})$. These islets displayed both a marked degranulation with margination of remaining granules and a marked increase of the roughsurfaced endoplasmic reticulum. Similar morphological observations have previously been reported after extended functional stimulation of islet B-cells in vivo [28] and in monolayer cultures of B-cells [24], but do not seem to have been described after short-term incubations of isolated islets. It is conceivable that structural changes of this kind reflect a stimulated insulin release and enhanced insulin biosynthesis in response to the high extracellular glucose concentration during the culture period. The abundance of ribosomes in the glucose stimulated islets is consistent with recent reports of an enhanced over-all rate of RNA synthesis in isolated rat islets subjected to short-term incubations at elevated glucose concentrations [29, 30,31].

The interpretation of the ultrastructural observations proposed above is strongly supported by the biochemical findings on the insulin content and release during culture. The degranulation of the high-glucose cultured islets corresponds to a rapid and pronounced depletion of stored insulin down to only $4 \%$ of the control value. The most conspicuous fall in the insulin content occurred during the first day of culture, which is in agreement with the observation that insulin accumulation in the culture medium was most rapid during this time. The subsequent increase of the insulin concentration in the medium proceeded at a relatively constant rate. Since the insulin content of the islets also gradually attained a steady state level the daily amount of insulin secreted into the medium during the subsequent culture period should correspond to the total amount of insulin formed per day by the B-cells, provided insulin degradation can be neglected. The latter process, as estimated by TCA precipitation of ${ }^{125}$ I-insulin, appeared most active in fresh culture medium and decreased within 2 days after a medium change. Bearing in mind these considerations, the approximate insulin production by the cultured islets could be estimated as $15 \mathrm{ng} / \mu \mathrm{g}$ islet protein during $24 \mathrm{hrs}$. With a total insulin content of only about $10 \mathrm{ng} / \mu \mathrm{g}$ islet protein the turn-over time for insulin in the highglucose cultured islets would thus be well below $24 \mathrm{hrs}$. Although this value may not be representative for the islets in vivo [32] it clearly shows that islets maintained at a high glucose concentration in stationary tissue culture are very active in both synthesis and release of insulin. It is of interest in this context that in human insulinomas there seems to be a small insulin pool with a high turn-over rate [33].

In contrast with the situation in the high-glucose cultured islets there was only a very small accumular tion of insulin in the culture medium when it contained a low glucose concentration. In fact, the insulin concentration remained essentially constant for several days, indicating that insulin secretion did not exceed insulin degradation during this period. Nevertheless, there was a gradual depletion of the islet insulin content, although at a considerably slower rate than observed in the high-glucose cultured islets. In line with this finding relatively well granulated B-cells were observed in the electron micrographs. It also appears from these pictures that fibroblastic overgrowth or dedifferentiation of the specific islet cells was not a likely cause of the insulin depletion. Neither were there any conspicuous signs of intracellular granulolysis by autophagosomal activity, as previously described in the $\mathrm{A}_{2}$-cells [34]. The changes of the islet insulin content would, therefore, best be explained by a suppressed biosynthesis of insulin due to the low glucose concentration in the culture medium.

Further insight about the long-term glucose effects on the insulin synthesis in cultured islets was gained by the studies of ${ }^{3} \mathrm{H}$-leucine incorporation into islet proteins. The radioactive incorporation pattern observed in the gel chromatograms was consistent with the known characteristics of that obtained with noncultured islets [35], irrespective of whether incorporation was allowed to proceed in a stationary culture system or in a short-term experiment after the culture period. Further characterization of the gel chromatographed islet proteins showed that the radioactive 
peaks containing proinsulin and insulin were not contaminated grossly with non-insulin proteins and therefore could provide a quantitative estimate of the leucine incorporation into each of these hormonal components. As previously pointed out by Sando et al. [13] the radioactivity recovered in the insulin region included also radioactivity of the $\mathrm{C}$-peptide, which is eluted together with insulin from Sephadex G-50 columns of this size [36].

Previous reports indicate that incorporation of labelled leucine into proinsulin reaches a steady state within a few hours of incubation, whereas labelling of the insulin pool continues at a linear rate for at least 12 hrs [37]. The increase in the ratio between the radioactivity in insulin and the total radioactivity in proinsulin -insulin reflects the degree of conversion of proinsulin ( $c f .13$ ). There is little evidence to suggest that this particular process is influenced by glucose, a view which is apparently corroborated by the present observation that in non-cultured islets the glucose concentration failed to affect the radioactive ratios after either 90 or $180 \mathrm{~min}$ incubation. However, islets cultured in the high-glucose medium had a much higher labelling in the insulin pool, particularly after $90 \mathrm{~min}$ incubation. It is not possible to say whether this observation reflects an increased rate of proinsulin-toinsulin conversion or merely the transfer of radioactivity from proinsulin with high specific activity into the insulin pool. It is nevertheless of interest that the conversion process obviously proceeded at a substantial rate, despite the fact that the B-cells of the high-glucose cultured islets were heavily degranulated. 'This finding supports the view that converting' enzymes are located not only in the membranes of the secretion granules but also in those of the Golgi complex [38, 39, 40].

It is generally accepted that glucose stimulates the biosynthesis of insulin in the mammalian B-cell, an effect that has been postulated as due to enhanced formation of RNA [29, 30, 31]. The present data on leucine incorpration into cultured islets showed clearly that the rate of insulin synthesis was correlated not only with the glucose concentration in the incubation medium, but also with that in the previous culture medium. This suggests that the B-cells are equipped with a "memory", which may regulate the rate of insulin biosynthesis in situations with rapidly changing extracellular glucose concentrations. The nature of a cellular mechanism of this kind remains to be clarified, but an influence of glucose on RNA metabolism seems possible [30]. The decreased rate of leucine incorporation into the high-glucose cultured islets after $180 \mathrm{~min}$ incubation would, on the other hand, reflect release of labelled insulin, since these islets have been found to secrete a substantial amount of their total insulin store within half an hour of incubation at $16.7 \mathrm{mM}$ glucose $[3]$.

The extremely high specific labelling of the insulin in the high-glucose cultured islets was due to the addition of newly synthesized, labelled insulin to a small total insulin pool. This was particularly well illustrated by several days culture in the presence of ${ }^{3}$ H-leucine, which produced a specific activity about 100 times higher than that obtained during $3 \mathrm{hrs}$ incubation of non-cultured islets. This degree of labelling would be theoretically sufficient for the use of such insulin in biological research [41]. Although the available amounts will of necessity be small it would be interesting to study biosynthetically labelled, homologous insulin with regard to its affinity for antibodies or its metabolism both in vivo and in vitro. Probably, even higher specific activities could be obtained by culture in a mixture of labelled amino acids.

Acknowledgements. This study was supported by grants from The University of Uppsala, The Swedish Diabetes Association and The Swedish Medical Research Council. We thank Dr. Christian Berne and Dr. Rolf Gunnarsson for valuable help with the immunoadsorption studies. The expert technical assistance of Miss Margareta Hazelius, Miss Annika Wagman and Mr. Hans Ekwall is gratefully acknowledged.

\section{References}

1. Andersson, A., Hellerström, C.: Metabolic characteristics of isolated pancreatic islets in tissue culture. Diabetes 21 (Suppl. 2), 546-554 (1972)

2. Howell, S.L., Taylor, K.W.: Potassium ions and the secretion of insulin by islets of Langerhans incubated in vitro. Biochem. J. 108, 17-24 (1968)

3. Andersson, A.: Long-term effects of glucose on the insulin release and glucose oxidation of mouse pancreatic islets maintained in tissue culture. Bio. chem. J. 140, 377-382 (1974)

4. Lowry, O.H., Rosebrough, N.J., Farr, A.L., Randall, R.J.: Protein measurement with the Folin phenol reagent. J. biol. Chem. 193, 265-275 (1951)

5. Heding, L. : Determination of total serum insulin (IRI) in insulin-treated diabetic patients. Diabetologia 8, $260-266$ (1972)

6. Brodal, B.P.: Evidence of enzymatic degradation of insulin in blood in vitro. Europ. J. Biochem. 18, 201 206 (1971)

7. Keen, H., Field, J.B., Pastan, I.H.: A simple method for in vitro metabolic studies using small volumes of tissue and medium. Metabolism 12, 143-147 (1963)

8. Gey, G.O., Gey, M.K.: The maintenance of human normal cells and tumor cells in continuous culture. Amer. J. Cancer 27, 45-49 (1936)

9. Eagle, H. : Amino acid metabolism in mammalian cell cultures. Science 130, $432-437$ (1959)

10. Davoren, P.R.: The isolation of insulin from a single eat pancreas. Biochim. biophys. Acta (Amst.) 63, $150-153(1962)$

11. Davis, B.J.: Disc electrophoresis. II. Method and application to human serum proteins. Ann. N.Y. Acad. Sci. 121, 404-427 (1964)

12. Morris, G.E., Korner, A.: The effect of glucose on insulin biosynthesis by isolated islets of Langerhans of the rat. Biochim. biophys. Acta (Amst.) 208, 404$413(1970)$

13. Sando, H., Borg, J., Steiner, D.F.: Studies on the secretion of newly synthesized proinsulin and insulin from isolated rat islets of Langerhans. J. clin. Invest. $51,1476-1485$ (1972) 
14. Asplund, K. : Effects of glueose on insulin biosynthesis in foetal and newborn rats. Horm. Metab. Res. 5, $410-415$ (1973)

15. Berne, C.: Personal communication.

16. Westman, J., Andersson, A., Hellerström, C., Peters son, B.: Ultrastructure of monolayer cultures of pancreatic islet cells. Acta diabet. lat. 7, 557-589 (1970)

17. Kostianovsky, M., Lacy, P.E., Greider, M.H., Still, M.F.: Long term (15 days) incubation of islets of Langerhans isolated from adult rats and mice. Lab. Invest. 27, 53-61 (1972)

18. Andersson, A., Petersson, B., Westman, J., Edwards, J., Lundquist, G., Hellerström, C.: Tissue culture of $\mathrm{A}_{2}$ cell-rich pancreatic islets isolated from guinea-pigs. J. Cell Biol. 57, $241-247$ (1973)

19. Stock, C., Kedinger, M., Haffen, K., Grenier, J.-F:: Culture organotypique d'ilots de Langerhans isolés chez la souris obèse hyperglycémique. Etude ultrastructurale. Biol. Gastroenterol. (Paris) 6, 205-215 (1973)

20. Murell, L.R., Morgan, C.R., Lazarow, A.: Mammalian pancreatic islet tissue in organ culture. II. Insulin contents of tissues and culture medium. Exp. Cell Res. 41, 365-375 (1966)

21. Lazarow, A., Wells, L.J., Carpenter, A.M., Hegre, O.D., Leonard, R. J., McEvoy, R. C.: Islet differentiation, organ culture and transplantation. Diabetes $\mathbf{2 2}$, $877-912(1973)$

22. Orei, L., Lambert, A.E., Kanazawa, Y., Amherdt, M., Rouiller, Ch., Renold, A.E.: Morphological and biochemical studies of $\mathbf{B}$ cells of fetal rat endocrine pancreas in organ culture. Evidence for (pro) insulin biosynthesis. J. Coll Biol. 50, 565-582 (1971)

23. Renold, A.E.: The beta cell and its responses: Summarizing remarks and some contributions from Geneva. Diabetes 21 (Suppl. 2), 619-631 (1972)

24. Orei, L., Like, A.A., Amherdt, M., Blondel, B., Kanazawa, Y., Marliss, E.B., Lambert, A.E., Wollheim, C.B., Renold, A.E.: Monolayer cell culture of neonatal rat pancreas: An ultrastructural and biochemical study of functioning endocrine cells. J. Ultrastruct. Res. 43, 270-297 (1973)

25. Sando, H., Kemmler, W., Rubonstein, A.H., Steiner, D. F.: Studies on insulin biosynthesis and secretion in isolated islets and a cultured beta cell tumour. In: Fritz, I.B. (ed.): Insulin action, pp $77-113$. New York: Academic Press 1972

26. Macchi, J.A., Beyer, W.R., Gapp, D.A., Blaustein, E.H., Beaser, S.B.: Monolayer cultures derived from neonatal hamster pancreas: Stimulation of immunoreactive insulin secretion and biosynthesis. Proc. Soc. exp. Biol. (N.Y.) 143, 335-339 (1973)

27. Yip, C.C., Schinmer, B.P.: Human pancreatic islet tumor cells maintained in vitro. Diabetologia 9, 251 254 (1973)
28. Kern, H., Logothetopoulos, J.: Steroid diabetes in the guinea pig. Studies on islet-cell ultrastructure and regeneration. Diabetes $19,145-154$ (1970)

29. Jarrett, R.J., Keen, H., Track, N. : Glucose and RNA synthesis in mammalian islets of Langerhans. Nature 213, 634-635 (1967)

30. Permutt, M. A., Kipnis, D.M.: Mechanism of glucose stimulation of insulin synthesis: A translational effect. Diabetes 19, $358(1970)$

31. Puchinger, H., Wacker, A.: Effect of glucose and tolbutamide on RNA synthesis in isolated islets of Langerhans from rat pancreas. FEBS letters 21, 14$16(1972)$

32. Track, N.S., Frerichs, H., Creutzfeldt, W.: Release of newly synthesized proinsulin and insulin from granulated and degranulated isolated rat islets. Diabetologia 9, 93-94, 1973

33. Creutzfeldt, C., Track, N.S., Creutzfeldt; W.: In vitro studies of the ratie of proinsulin and insulin turnover in seven human insulinomas. Europ. J. clin. Invest. 3, $371-384(1973)$

34. Orci, L., Junod, A., Pictet, R., Renold, A. E., Rouiller, Ch.: Granulolysis in A cells of endocrine pancreas in spontaneous and experimental diabetes in animals. J. Cell Biol. 38, 462-465 (1968)

35. Steiner, D.F., Cunningham, D.D., Spiegelman, L., Aten, B.: Insulin biosynthesis: evidence for a precursor. Science 157, 697-700 (1967)

36. Clark, J.L., Steiner, D.F.: Insulin biosynthesis in the rat: Demonstration of two proinsulins. Proc. nat. Acad. Sci. (Wash.) 62, 278-285 (1969)

37. Steiner, D.F., Clark, J.L., Nolan, D., Rubenstein, A.H., Margoliash, E., Aten, B., Oyer, P.E.: Proinsulin and the biosynthesis of insulin. Recent Progr. Hormone Res. 25, 207-282 (1969)

38. Howell, S.L.: Role of ATP in the intracellular trans. location of proinsulin and insulin in the rat pancreatic B-cell. Nature New Biology 235, 85-86 (1972)

39. Steiner, D.F., Kemmler, W., Clark, J. L.. Oyer, P.E., Rubenstein, A.H.: The biosynthesis of insulin. In: Steiner, D.F., Freinkel, N. (eds.): Handbook of Phy. siology, Section 7. Endocrinology. Vol. 1. Endocrine Pancreas. pp. 175-198. Washington D.C.: American Physiological Society, 1972

40. Sun, A.M., Lin, B.J., Haist, R.E.: Studies on the conversion of proinsulin to insulin in the isolated islets of Langerhans in the rat. Can. J. Physiol. Pharmacol. $51,175-182(1973)$

41. Humbel, R.E.: Biosynthesis of insulin. In: Dörzbach, E. (ed.): Handb. Exp. Pharm. XXXXI/1. Insulin 1. pp. 313-320. Berlin: Springer-Verlag 1971

Dr. A. Andersson

Department of Histology

Biomedicum

Box 571

S-75123 Uppsala

Sweden 